\title{
Heterogeneous Integration of Adult-Generated Granule Cells into the Epileptic Brain
}

\author{
Brian L. Murphy, ${ }^{1,3 *}$ Raymund Y. K. Pun, ${ }^{1 \star}$ Hulian Yin, ${ }^{1}$ Christian R. Faulkner, ${ }^{1}$ Andreas W. Loepke, ${ }^{1,2,3}$ \\ and Steve C. Danzer ${ }^{1,2,3}$ \\ ${ }^{1}$ Department of Anesthesia, Cincinnati Children's Hospital Medical Center, Cincinnati, Ohio 45229, ${ }^{2}$ Departments of Anesthesia and Pediatrics, University \\ of Cincinnati, Cincinnati, Ohio 45221, and ${ }^{3}$ Program in Neuroscience, University of Cincinnati, Cincinnati, Ohio 45229
}

The functional impact of adult-generated granule cells in the epileptic brain is unclear, with data supporting both protective and maladaptive roles. These conflicting findings could be explained if new granule cells integrate heterogeneously, with some cells taking neutral or adaptive roles and others contributing to recurrent circuitry supporting seizures. Here, we tested this hypothesis by completing detailed morphological characterizations of age- and experience-defined cohorts of adult-generated granule cells from transgenic mice. The majority of newborn cells exposed to an epileptogenic insult exhibited reductions in dendritic spine number, suggesting reduced excitatory input to these cells. A significant subset, however, exhibited higher spine numbers. These latter cells tended to have enlarged cell bodies, long basal dendrites, or both. Moreover, cells with basal dendrites received significantly more recurrent mossy fiber input through their apical dendrites, indicating that these cells are robustly integrated into the pathological circuitry of the epileptic brain. These data imply that newborn cells play complex —and potentially conflicting-roles in epilepsy.

\section{Introduction}

Adult-generated hippocampal granule cells undergo a stereotypical developmental pattern, culminating in mature neurons with characteristic dendritic structures, axonal projection patterns, afferent inputs, and efferent targets (Markakis and Gage, 1999; Ambrogini et al., 2004; Overstreet et al., 2004; Laplagne et al., 2006; Toni et al., 2007, 2008). In the normal brain, this process is remarkable for its consistency, producing neurons that bear the key features of granule cells generated early in development (van Praag et al., 2002; Espósito et al., 2005; Zhao et al., 2006; Rahimi and Claiborne, 2007; Toni et al., 2008). By contrast, in the epileptic brain, granule cell integration is profoundly disrupted (Parent, 2007). In particular, immature granule cells exposed to seizures exhibit migration defects (Scharfman et al., 2000; McCloskey et al., 2006; Parent et al., 2006; Jessberger et al., 2007; Scharfman et al., 2007; Walter et al., 2007), develop aberrant basal dendrites (Ribak et al., 2000; Shapiro and Ribak, 2006; Jessberger et al., 2007; Walter et al., 2007), and contribute to mossy fiber sprouting (Parent et al., 1997; Danzer, 2008; Kron et al., 2010). Although the nature of these morphologic abnormalities suggests

\footnotetext{
Received May 28, 2010; revised Sept. 8, 2010; accepted 0ct. 21, 2010.

This work was supported by Cincinnati Children's Hospital Medical Center, the Epilepsy Foundation of America, and the National Institute of Neurological Disorders and Stroke (Grants R01NS065020 and R01NS062806). We thank Keri Kaeding and Dr. David Richards for useful comments on earlier versions of this manuscript.

The content is solely the responsibility of the authors and does not necessarily represent the official views of the National Institute of Neurological Disorders and Stroke or the National Institutes of Health.

*B.L.M. and R.Y.K.P contributed equally to this work.

Correspondence should be addressed to Dr. Steve C. Danzer, 3333 Burnet Avenue, ML 2001, Cincinnati, $\mathrm{OH}$ 45229-3039. E-mail: steve.danzer@cchmc.org.

Neuronal reconstructions are available at www.NeuroMorpho.Org.

DOI:10.1523/JNEUROSCI.2728-10.2011

Copyright $\odot 2011$ the authors $\quad 0270-6474 / 11 / 310105-13 \$ 15.00 / 0$
}

that the affected cells might contribute to the development of epilepsy (Parent and Lowenstein, 2002), only a subset of newborn cells are disrupted (Jessberger et al., 2007; Walter et al., 2007), and whether these cells exhibit other, potentially compensatory, changes is not known. Further confusing the matter, physiologic studies suggest that newborn cells in the epileptic brain receive less excitatory synaptic input than age-matched cells from control animals (Jakubs et al., 2006). The net effect of adult neurogenesis in epilepsy, therefore, remains controversial.

This controversy could be explained, in part, if adultgenerated granule cells are not homogeneous. Indeed, the existence of new cells with and without basal dendrites is already an indication of significant heterogeneity. Lacking, however, is a detailed characterization of newborn granule cells in the epileptic brain. This information is essential for determining whether distinct subpopulations of newborn granule cells are present, and to identify which, if any, newborn cells are likely to contribute to epilepsy.

Here, two transgenic mouse model approaches were used to characterize the morphological development of granule cells maturing under control and epileptogenic conditions. BrdUtreated, Thy1-GFP-expressing mice were used to reveal populations of 12-week-old adult-generated cells, and complementary data were generated using conditional, inducible Gli1-CreER ${ }^{\mathrm{T} 2} \times$ GFP reporter mice. Morphological approaches were selected because they provide robust information that can be used to predict cellular function, without the need for substantial a priori knowledge about how cell function might be altered. Three key parameters were examined. First, newborn granule cells were reconstructed to assess dendritic structure and branching patterns. Second, dendritic spine number was quantified in the middle and outer molecular layers to assess the relative strength of excitatory 
inputs from medial and lateral entorhinal cortex, respectively, and inner molecular layer spine number was quantified to assess the impact of mossy cell and interneuron loss-populations that normally innervate this layer and degenerate in epilepsy. Third, innervation by sprouted mossy fiber axons was quantified to gauge the recruitment of newborn cells into the recurrent circuitry of the epileptic brain. These morphological features were systematically analyzed to identify traits common to granule cells likely receiving high levels of afferent and recurrent excitatory input.

\section{Materials and Methods}

All procedures conformed to the National Institutes of Health's and institutional guidelines for the care and use of animals.

Thy1-GFP mice. Thyl-GFP-expressing mice were kindly provided by Dr. Guoping Feng (Duke University, Durham, NC) (Feng et al., 2000). All Thyl-GFP mice in the present study were hemizygous for the Thyl-GFP transgene and were maintained on a C57BL/6 background. For BrdU/GFP double-labeling experiments, a total of seven male control and seven male pilocarpine-treated mice were used.

Starting at 11 weeks of age, mice were given once-daily subcutaneous injections of $\mathrm{BrdU}$ ( $100 \mathrm{mg} / \mathrm{kg}$ in Ringers solution) for $3 \mathrm{~d}$. At 12 weeks of age, mice were injected with $1 \mathrm{mg} / \mathrm{kg}$ methyl scopolamine nitrate subcutaneous in saline solution. Fifteen minutes later, mice were injected subcutaneous with $380 \mathrm{mg} / \mathrm{kg}$ pilocarpine in saline. All pilocarpine treatments were conducted between 10 A.M. and noon to control for diurnal variations. Mice were observed following the injections for the development of status epilepticus, defined behaviorally by continuous tonic/clonic convulsions. Three hours after the onset of status epilepticus, mice were given two doses of $10 \mathrm{mg} / \mathrm{kg}$ diazepam at $15 \mathrm{~min}$ intervals. Mice were housed in a $32^{\circ} \mathrm{C}$ incubator for the next $48 \mathrm{~h}$ and given subcutaneous saline warmed to $37^{\circ} \mathrm{C}$ to maintain pretreatment weight and improve recovery. Control animals received all drugs and treatments except they were given saline injections instead of pilocarpine. Litters were divided so that littermates were represented in both control and experimental groups. At 23 weeks of age, mice were overdosed with pentobarbital $(100 \mathrm{mg} / \mathrm{kg})$ and perfused with $0.1 \mathrm{~m}$ PBS plus $1 \mathrm{U} / \mathrm{ml}$ heparin, followed by $2.5 \%$ paraformaldehyde and $4 \%$ sucrose in PBS, $\mathrm{pH} 7.4$. Brains were postfixed for $12 \mathrm{~h}$, cryoprotected in sucrose $(10,20$, or $30 \%)$, and coronal sections were cut on a cryostat at $60 \mu \mathrm{m}$. Slide mounted sections were stored at $-80^{\circ} \mathrm{C}$ until use.

Gli1-CreER $R^{T 2} \times$ GFP reporter mice. Gli1-CreER ${ }^{\mathrm{T} 2}$ mice were generously provided by Dr. Alexandra Joyner (Sloan-Kettering Institute, New York, NY). These animals express tamoxifen-inducible Cre recombinase under the control of the Glil promoter (GLI-Kruppel family member), which drives expression in sonic hedgehog-responding progenitor cells (Ahn and Joyner, 2004, 2005). GFP reporter mice (Nakamura et al., 2006) were graciously provided by Dr. Jeffrey Robbins (Cincinnati Children's Research Foundation, Cincinnati, $\mathrm{OH})$. Mice were maintained on a C57BL/6 background and eight male and female mice (control, 3 male, 1 female; pilocarpine-treated, 1 male, 3 female; no effect of sex was found for any of the measures reported here; data not shown) hemizygous for the Gli1-CreER ${ }^{\mathrm{T} 2}$ transgene and heterozygous for the GFP reporter transgene were used for experiments. Mice were treated with $425 \mathrm{mg} / \mathrm{kg}$ pilocarpine when the animals were between 4 and 6 weeks of age using a protocol otherwise identical to that used for Thyl-GFP mice. Mice were given two $700 \mathrm{mg} / \mathrm{kg}$ subcutaneous doses of tamoxifen (Sigma) dissolved in corn oil 8 and $9 \mathrm{~d}$ after pilocarpine treatment (one dose per day). Three months after tamoxifen treatment, mice were perfused and tissue collected and processed as described for Thyl-GFP mice.

Immunohistochemistry. BrdU and GFP double-immunostaining was conducted using the following protocol: slide-mounted sections were thawed in Tris buffer $(0.02 \mathrm{M}$ Tris- $\mathrm{HCl}, \mathrm{pH}$ 7.6), incubated for $1 \mathrm{~h}$ in $0.5 \%$ Igepal in Tris buffer and for $30 \mathrm{~min}$ in $3 \mu \mathrm{g} / \mathrm{ml}$ protease (P6911; Sigma) with $20 \mathrm{~mm} \mathrm{CaCl}$ at $37^{\circ} \mathrm{C}$ in Tris buffer. Sections were then incubated for $10 \mathrm{~min}$ in ice-cold $0.1 \mathrm{M} \mathrm{HCl}$ in $\mathrm{dH}_{2} \mathrm{O}$, for $20 \mathrm{~min}$ in $2 \mathrm{M}$ $\mathrm{HCl}$ in $0.05 \mathrm{M} \mathrm{PBS}$ at $37^{\circ} \mathrm{C}$, and for $10 \mathrm{~min}$ in $0.1 \mathrm{~m}$ borate buffer, $\mathrm{pH}$ 8.5. Sections were incubated for $1 \mathrm{~h}$ in blocker [ $5 \%$ normal goat serum (Invitrogen) plus $0.5 \%$ Igepal in $0.1 \mathrm{M} \mathrm{PBS}, \mathrm{pH} 7.4$ ]. Sections were then incubated overnight at $4^{\circ} \mathrm{C}$ in $1: 200$ mouse monoclonal antiBrdU (Becton Dickinson) and $5 \mu \mathrm{g} / \mathrm{ml}$ rabbit polyclonal anti-GFP antibody (AB3080; Millipore Bioscience Research Reagents) in blocker. Sections were then rinsed in blocker and incubated for $4 \mathrm{~h}$ at room temperature in 1:750 Alexa Fluor 594 goat anti-mouse and 1:750 Alexa Fluor 488 goat anti-rabbit antibodies (Invitrogen). After rinsing in PBS, sections were dehydrated in alcohols, cleared in xylenes, and mounted with Cytoseal.

Immunolabeling for GFP and zinc transporter 3 (ZnT-3) was conducted on slide-mounted sections (McAuliffe et al., 2010). Sections were thawed in PBS, blocked for $1 \mathrm{~h}$ with $0.5 \%$ Igepal plus 5\% normal goat serum in PBS, and incubated overnight in chicken anti-GFP (1:3000, ab13970; Abcam) and rabbit anti-ZnT-3 (1:3000; Synaptic Systems) antibodies in blocker at $4^{\circ} \mathrm{C}$. Sections were then rinsed in blocker and incubated for $2 \mathrm{~h}$ in 1:750 Alexa Fluor 488 goat antichicken and 1:750 Alexa Fluor 594 goat anti-rabbit secondary antibodies (Invitrogen).

Confocal microscopy of newborn granule cells. In all cases, neuron selection and imaging were conducted with the investigator blinded to treatment group. BrdU-positive, GFP-expressing dentate granule cells were identified by screening immunostained sections from Thyl-GFP mice under epifluorescent illumination. GFP-labeled cells (with dendrites that could be followed to their endings and clearly visible dendritic spines), with their somas contained within the tissue section and within the granule cell body layer, were used for reconstructions. All granule cells selected for analyses needed to possess at least one dendritic branch that terminated naturally (i.e., not cut at the tissue surface). Hilar ectopic granule cells were not examined in the present study because, based on 


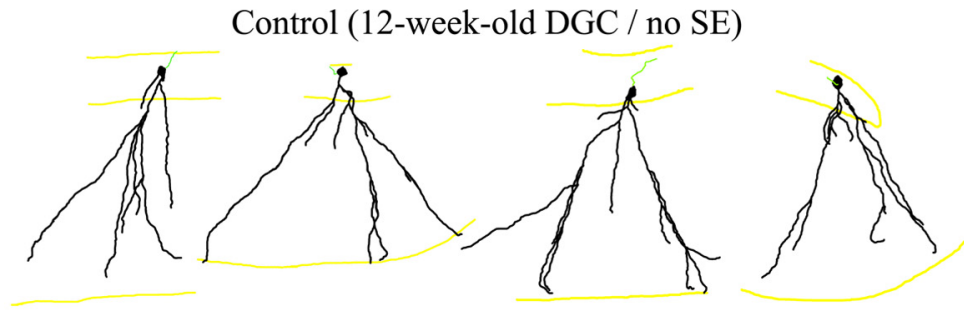

Status Epilepticus (12-week-old DGC / SE at $1 \mathrm{wk}$ )

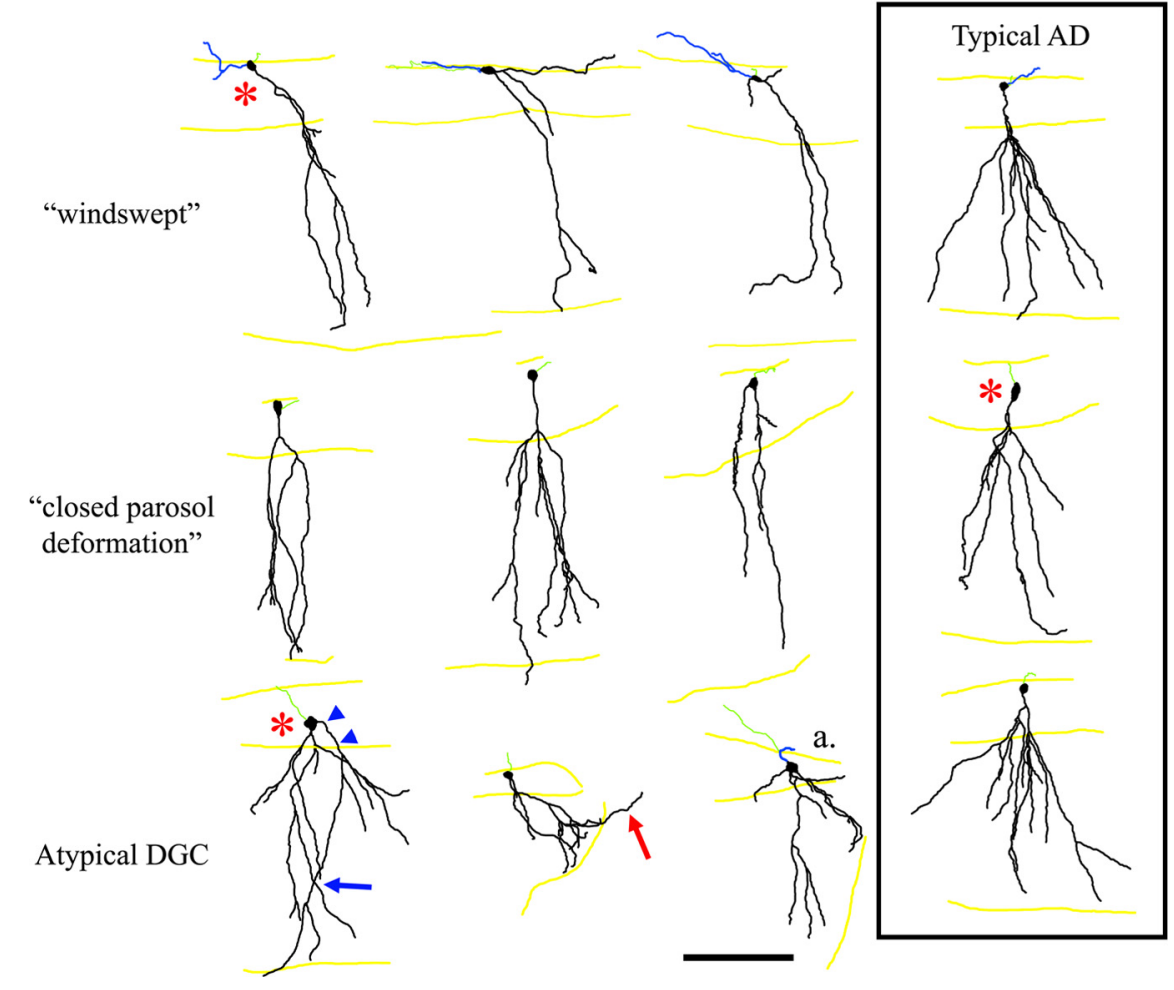

Figure 2. Neurolucida reconstructions of newborn granule cells from Thy1-GFP-expressing control animals (top row) and animals treated with pilocarpine to induce status epilepticus. All cells are 12-weeks-old, and cells from epileptic animals were exposed to status when these cells were 1-week-old. Black, Apical dendrites (AD); blue, basal dendrites; green, axons. Yellow lines, Borders of the granule cell body layer and the hippocampal fissure. Although many granule cells from epileptic animals exhibited the normal fanlike dendrite trees (box) typical of cells from control animals, a subset of cells exhibited trees that were heavily lateralized (windswept appearance) or trees that failed to spread within the molecular layer (closed-parasol deformation). Finally, several cells exhibited irregular dendritic trees $(a)$ that were difficult to characterize, but included abnormalities such as recurrent basal dendrites (arrowheads), crossing dendrites (blue arrow), and dendrites that projected outside of the molecular layer (red arrow). Red asterisks, Granule cells with high spine densities. Scale bar, $100 \mu \mathrm{m}$.

location alone, $100 \%$ of these cells are abnormal (Scharfman et al., 2000, 2003; Pierce et al., 2005). Rather, the present study focuses on the majority population of newborn cells correctly located in the granule cell layer. The extent to which abnormalities are present in this population is uncertain, and indeed, it has been suggested that these cells may be nonepileptogenic (Scharfman and McCloskey, 2009). Double-labeled granule cells were imaged using a Leica SP5 confocal microscope set up on a DMI6000 inverted microscope equipped with a $63 \times$ oil-immersion objective (numerical aperture, 1.4). For dendritic reconstructions, threedimensional Z-series stacks were captured at $0.5 \mu \mathrm{m}$ increments at $2 \times$ optical zoom (field size, $120 \times 120 \mu \mathrm{m}$ ). For analyses of the dendritic spines of BrdU-positive, GFP-expressing dentate granule cells, Z-series stacks were captured at $0.2 \mu \mathrm{m}$ increments at $6 \times$ optical zoom (field size, $40 \times 40 \mu \mathrm{m}$ ). Stacks were obtained of dendritic segments located in the dentate granule cell layer and the inner, middle, and outer molecular layers (Fig. 1).

Molecular layer border granule cells. Sections used for identifying BrdU-labeled, GFP-expressing cells were screened to find BrdU- negative, GFP-expressing dentate granule cells with their somas located on the granule cell body layer-molecular layer border (MLB). MLB granule cells were selected using the same criteria as for BrdU-labeled, GFP-expressing cells, with the exceptions that all cells were BrdU-negative and only cells with their somas located on or within one cell body diameter of the molecular layer border were used. To minimize variability, cell selection was restricted to the upper blade of the dentate and all cells meeting selection criteria were used until a predetermined target sample size was met (three to six neurons per animal). Confocal imaging and neuronal reconstruction was performed as described for BrdU-positive, GFP-expressing (newborn) cells. Finally, we note that MLB granule cells occupy a unique position in the granule cell body layer and exhibit distinct morphological features (Claiborne et al., 1990; Dashtipour et al., 2002). Comparisons between MLB granule cells from control and epileptic animals are valid; however, comparing these cells to cells with their somas located in other regions of granule cell body layer should be done with caution. Granule cells in different regions of the dentate may exhibit distinct morphological, physiological, and plastic capabilities.

Analysis of sprouted mossy fiber axons. ZnT-3 immunolabeling of presumptive mossy fiber presynaptic terminals apposed to GFP-expressing dendritic spines were imaged by confocal microscopy using a $63 \times$ objective at $6 \times$ optical zoom. Z-series stacks were captured at $0.2 \mu \mathrm{m}$ increments. Two-channel sequential scans were captured using 488 and $543 \mathrm{~nm}$ laser excitation and emissions between 500 and 550 $\mathrm{nm}$ (AF488 secondary) and 600 and $660 \mathrm{~nm}$ (AF594 secondary) were captured. To ensure that differences in antibody penetration did not create a bias, only dendritic segments located $10 \mu \mathrm{m}$ or less from the tissue surface were used. Three populations of granule cells were imaged from Gli1-CreER ${ }^{\mathrm{T} 2} \times$ GFP reporter mice, as follows: group 1, GFP-expressing granule cells from control animals; group 2, GFP-expressing granule cells from epileptic animals possessing a basal dendrite projecting at least to the midpoint of the hilus; and group 3 , the nearest GFP-expressing neighbor to each group 2 cell that lacked a basal dendrite. Restated, each group 2 cell is paired with a group 3 cell from the identical location, thus controlling for regional differences in cell loss, mossy fiber sprouting, et cetera. Morphologically immature granule cells, which could be easily identified because their apical dendrites terminate well short of the hippocampal fissure (Jones et al., 2003), were excluded from analysis.

Neuronal reconstructions. Neurons were digitally reconstructed from confocal image stacks using Neurolucida software (Microbrightfield) by an observer unaware of treatment group. Multiple image stacks were required to capture neurons with sufficient resolution, so overlapped image stacks were three-dimensionally montaged into a single image using Neurolucida software. Reconstructions encoded soma area, apical and basal dendrite length, and dendritic branch points. Dendritic endings were encoded as either "natural," meaning the natural termination of dendrite was contained within the tissue section, or as "cut" if the ending was truncated at the upper or lower surface of the slice. To control for regional differences, the 
Table 1. Dendritic structure of newborn cells exposed to status epilepticus versus control cells

\begin{tabular}{|c|c|c|c|c|c|c|c|c|c|c|c|}
\hline & \multirow{2}{*}{\multicolumn{2}{|c|}{$\begin{array}{l}\text { No. of } \mathrm{BD} \text { length } \\
\text { cells }(\mu \mathrm{m})\end{array}$}} & \multirow{2}{*}{$\begin{array}{l}\text { Soma area } \\
\left(\mu \mathrm{m}^{2}\right)\end{array}$} & \multirow{2}{*}{$\begin{array}{l}A D \\
\text { number }\end{array}$} & \multirow{2}{*}{$\begin{array}{l}\text { AD branch } \\
\text { points }\end{array}$} & \multicolumn{6}{|l|}{ AD length } \\
\hline & & & & & & DGC-L layer & IML & MML & OML & Total & EST. total \\
\hline Newborn control & & $0.0(0-0)$ & $55.5(35.7-94.3)$ & $1.0(1-2)$ & $6.0(4-10)$ & $75.3(22-121)$ & $130.2(93-226)$ & $315.4(96-525)$ & $204.5(79-353)$ & $786.0(432.9-956.2)$ & 1277 (923-1793) \\
\hline Newborn SE & 44 & $0.0^{*}(0-232)^{a}$ & $65.3(38.7-127.7)$ & $1.0(1-4)$ & $6.5(2-19)$ & $79.0(34-222)$ & $152.5(48-405)$ & $338.0(45-798)$ & $215.1(0-508)$ & $831.0(210.9-1282.5)$ & $1350(574-2104)$ \\
\hline
\end{tabular}

AD, Apical dendrite; DGC-L, DGC layer; MML, middle molecular layer; $0 M L$, outer molecular layer. Values are medians (range). ${ }^{*} p<0.001$, Mann-Whitney RST. Significant values are in bold.

${ }^{a}$ The median value of zero reflects the fact that 23 of 44 cells had no basal dendrites (thus BD length $=0$ for these cells).

position of each cell's soma was determined, including its location in the upper or lower blade of the dentate and its distance from the dentate granule cell layer-hilar border. The anterior-posterior position (relative to bregma) of the brain section that each cell was obtained from was determined using Paxinos and Franklin's mouse brain atlas (2001). These three measures of cell position were all statistically equivalent among groups (supplemental Table 1, available at www.jneurosci.org as supplemental material). Finally, borders between the granule cell layer and the hilus, the granule cell layer and the molecular layer, and the molecular layer and the hippocampal fissure were encoded. The molecular layer was then subdivided into three regions, as follows: the innermost $17 \%$ of the layer was identified and defined as the inner molecular layer (West and Andersen, 1980; Deller et al., 1999; van Groen et al., 2003; Danzer et al., 2004), and the remaining $83 \%$ was subdivided equally into middle and outer molecular layer regions (Fig. 1). Notably, however, the exact borders between the layers are not always clearly discernable and vary slightly in different regions of the dentate, so values should be interpreted only as estimates.

The dendritic spread of granule cells exceeds the thickness of the 60 $\mu \mathrm{m}$ sections used in the present study, so all of the cells examined possessed artificially truncated dendritic branches. Since all groups were treated identically, comparisons are valid; indeed, the number of truncated processes was equivalent among groups (supplemental Table 1, available at www.jneurosci.org as supplemental material); however, truncation effects would introduce a bias against larger cells. To compensate for this bias, the terminal branch order of dendrites with natural endings was used as an additional measure (supplemental Fig. 1, available at www.jneurosci.org as supplemental material). Terminal branch order is directly related to the number of branches along the dendrite (terminal branch order $=$ number of branches +1 ) and since only natural endings were used, the resulting average terminal branch order for each cell provides a measure of dendritic branching that is more resistant to truncation effects. In addition, estimates of total apical dendrite length were generated to further mitigate truncation effects. Estimates were generated taking advantage of the fact that, with infrequent exceptions, the dendrites of mature granule cells are self-similar and tend to follow a predictable trajectory with processes terminating at the hippocampal fissure. Using Neurolucida software, therefore, truncated endings were identified and then drawn out to the hippocampal fissure along the same trajectory as the truncated process (supplemental Fig. 1, available at www.jneurosci.org as supplemental material). This approach still tends to underestimate total dendritic length, as we did not attempt to predict the number of missing branches (some truncated processes surely branch after the truncation). It almost certainly, however, improves the dataset, as it follows the reasonable assumption that the more truncated processes a cell has, and the closer these truncations are to the soma, the more length is missing. With this approach, estimates will be most accurate close to the cell body and least accurate with greater distance from the truncated process. Both raw and estimated data are presented in the results, with estimates indicated by the prefix "EST" for clarity. Finally, although these solutions are helpful, they are still imperfect, so measures of dendritic structure and spine number should be interpreted with this caveat in mind.

Spine counts. Dendritic spines were counted by a blinded observer from confocal image stacks using Neurolucida software (Danzer et al., 2008). Spines were defined as protrusions from the main dendritic shaft exceeding $0.25 \mu \mathrm{m}$ in length. Only dendritic segments fully contained within the Z-depth of the image stack (such that regions above and below the dendrite were visible) were used for spine-count analyses. Since spines were counted from confocal images, it was possible to identify spines both above and below the dendrite in addition to spines projecting perpendicular to the $z$ axis, although it is likely that smaller Z-projecting spines could still be missed. This applies equally to all groups, however, so relative differences in spine density reported here are comparable among groups, although these values may underestimate true spine numbers. Finally, for determining the number of spines receiving putative mossy fiber terminal input in Gli1-CreER ${ }^{\mathrm{T} 2} \times$ GFP reporter mice, GFP-labeled spines were counted from confocal image stacks, as described above. Spines directly apposed to ZnT-3-immunoreactive puncta were scored as positive for receiving mossy fiber input. Puncta were defined as accumulations of ZnT-3 immunoreactivity with a diameter $>0.5 \mu \mathrm{m}$.

Statistics. All statistical tests were performed using SigmaStat (version 11.0; SPSS). Parametric tests were used for data that met assumptions for normality and equal variance. Data that violated these assumptions were either normalized before running a parametric test, or a nonparametric version of the test was run. Specific tests were used as noted in the results. Data are presented as either means \pm SEM or as median (range). Statistical significance was accepted for $p<0.05$.

Figure preparation. Images presented in the figures are confocal maximum projections and were prepared using Leica's LAS-AF Confocal software (1.3.1 build 525). These images were processed using an erosion filter run for one iteration with a three pixel radius (Leica software) to reduce background artifact. Images were also cropped in the $z$ axis, as needed, to remove structures belonging to other cells. Although these adjacent cells can be readily distinguished in threedimensional image stacks, they would obscure the cell of interest in the two-dimensional format presented here. These images are rightly viewed as neuronal reconstructions, therefore, rather than standard micrographs (Walter et al., 2007). Brightness and contrast of digital images were adjusted using Adobe Photoshop (version 7.0) to maximize detail. In all cases, identical adjustments were made to images meant for comparison.

\section{Results}

\section{Altered apical dendritic structure among newly generated granule cells exposed to status epilepticus}

Brain sections from Thy1-GFP-expressing control animals and animals that underwent pilocarpine-induced status epilepticus (SE) were screened to identify BrdU-labeled, GFP-expressing dentate granule cells (DGCs). Eighteen cells from seven control animals and 44 cells from seven epileptic animals were identified for reconstruction. Cells were selected from dorsal hippocampus, so findings are limited to this region. BrdU-labeled, GFP-expressing granule cells from control animals exhibited the typical morphology of mature granule cells (Claiborne et al., 1990), with round cell bodies located in the granule cell layer, fanlike dendritic trees extending to the hippocampal fissure, and an absence of basal dendrites (Fig. 2). By contrast, half of the granule cells born just before status epilepticus exhibited aberrant hilar basal dendrites, consistent with previous studies (Walter et al., 2007).

Obvious qualitative apical dendrite abnormalities were evident among 27\% (12 of 44) of granule cells born just before status. By contrast, gross abnormalities were absent among cells from control animals ( 0 of $18 ; p=0.013$, Fisher exact test). Ab- 
Table 2. Structure of naturally terminating dendrites from newborn cells exposed to status epilepticus versus control cells

\begin{tabular}{|c|c|c|c|c|c|c|c|c|}
\hline & $\begin{array}{l}\text { AD length } \\
\text { to natural } \\
\text { ending }\end{array}$ & $\begin{array}{l}\text { Terminal branch } \\
\text { order of natural } \\
\text { endings }\end{array}$ & $\begin{array}{l}\text { 1st order } \\
\text { segment } \\
\text { length }\end{array}$ & $\begin{array}{l}\text { 2nd order } \\
\text { segment } \\
\text { length }\end{array}$ & $\begin{array}{l}\text { 3rd order } \\
\text { segment } \\
\text { length }\end{array}$ & $\begin{array}{l}\text { 4th order } \\
\text { segment } \\
\text { length }\end{array}$ & $\begin{array}{l}\text { 5th order } \\
\text { segment } \\
\text { length }\end{array}$ & $\begin{array}{l}\text { Terminal } \\
\text { segment } \\
\text { length }\end{array}$ \\
\hline Newborn control & $228.8(178-268)$ & $4.6(3-8)$ & $15.3(2.2-46.3)$ & $11.1(1.3-103.9)$ & $25.3(10.6-126.6)$ & $82.4(0.5-193.3)$ & $75.0(10.7-202.8)$ & $121.9(49.8-202.8)$ \\
\hline Newborn SE & $238.9(126-281)$ & $4.0(2-7)$ & $23.3(1.9-85.5)$ & $23.9(2.3-134.8)^{* *}$ & $42.6(4.5-151.3)^{*}$ & $63.4(6.8-205.6)$ & $75.4(5.4-191.8)$ & $109.9(33.1-223.2)$ \\
\hline
\end{tabular}

$\mathrm{AD}$, Apical dendrite. Values are medians (range). ${ }^{*} p=0.045,{ }^{* *} p=0.009$, Mann-Whitney rank sum test. Significant values are in bold. Only naturally terminating (or branching) segments are presented here.

Table 3. Dendritic structure of molecular layer border granule cells exposed to status epilepticus versus control cells

\begin{tabular}{|c|c|c|c|c|c|c|c|c|c|c|c|}
\hline & \multirow{2}{*}{$\begin{array}{l}\text { No. of } \\
\text { cells }\end{array}$} & \multirow{2}{*}{$\begin{array}{l}\text { BD length } \\
(\mu \mathrm{m})\end{array}$} & \multirow{2}{*}{$\begin{array}{l}\text { Soma area } \\
\left(\mu \mathrm{m}^{2}\right)\end{array}$} & \multirow{2}{*}{$\begin{array}{l}A D \\
\text { number }\end{array}$} & \multirow{2}{*}{$\begin{array}{l}\text { AD branch } \\
\text { points }\end{array}$} & \multicolumn{6}{|l|}{ AD length } \\
\hline & & & & & & DGC-L layer & IML & MML & OML & Total & EST. total \\
\hline MLB Control & 21 & $0.0(0-0)$ & $69.7(36.8-119.6)$ & $2.0(1-5)$ & $7.0(3-11)$ & $18.3(0-78)$ & $173.5(112-304)$ & $431.4(252-772)$ & $290.8(159-681)$ & $926.2(670-1657)$ & $1658.0(1157-2194)$ \\
\hline MLB SE & 20 & $0.0(0-0)$ & $59.5(40.9-103.2)$ & $2.0(1-3)$ & $7.5(4-10)$ & $20.7(0-96)$ & $183.5(82-286)$ & $373.1(189-652)$ & $314.0(132-696)$ & 891.7 (621-1441) & $1608.3(1196-1963)$ \\
\hline
\end{tabular}

AD, Apical dendrite; DGC-L, DGC layer; MML, middle molecular layer; OML, outer molecular layer. Values are medians (range). No significant differences were found between groups.

Table 4. Structure of naturally terminating dendrites from molecular layer border granule cells exposed to status epilepticus versus control cells

\begin{tabular}{|c|c|c|c|c|c|c|c|c|}
\hline & $\begin{array}{l}\text { AD length } \\
\text { to natural } \\
\text { ending }\end{array}$ & $\begin{array}{l}\text { Terminal branch } \\
\text { order of natural } \\
\text { endings }\end{array}$ & $\begin{array}{l}\text { 1st order } \\
\text { segment } \\
\text { length }\end{array}$ & $\begin{array}{l}\text { 2nd order } \\
\text { segment } \\
\text { length }\end{array}$ & $\begin{array}{l}\text { 3rd order } \\
\text { segment } \\
\text { length }\end{array}$ & $\begin{array}{l}\text { 4th order } \\
\text { segment } \\
\text { length }\end{array}$ & $\begin{array}{l}5^{\text {th }} \text { order } \\
\text { segment } \\
\text { length }^{a}\end{array}$ & $\begin{array}{l}\text { Terminal } \\
\text { segment } \\
\text { length }\end{array}$ \\
\hline MLB Control & $216.1(168-238)$ & $4.0(2.0-5.6)$ & $11.3(1.4-109.3)$ & $33.7(3.3-123.2)$ & $59.7(10.8-103.9)$ & $86.7(6.3-154.9)$ & $63.4(43.2-145.0)$ & $133.5(45.4-218.2)$ \\
\hline MLB SE & $200.3 *(170-258)$ & $3.8(2.8-6.0)$ & $14.4(2.3-33.1)$ & $40.8(3.0-97.1)$ & $67.2(9.9-143.5)$ & $72.8(26.3-179.5)$ & $106.7(8.1-156.2)$ & $100.5^{*}(49.3-176.0)$ \\
\hline
\end{tabular}

$A D$, Apical dendrite. Values are medians (range). ${ }^{*} p<0.05$, Mann-Whitney RST. Significant values are in bold.

Only naturally terminating (or branching) segments are presented here.

${ }^{a}$ Only seven control and nine SE cells possessed any 5 th order segments.
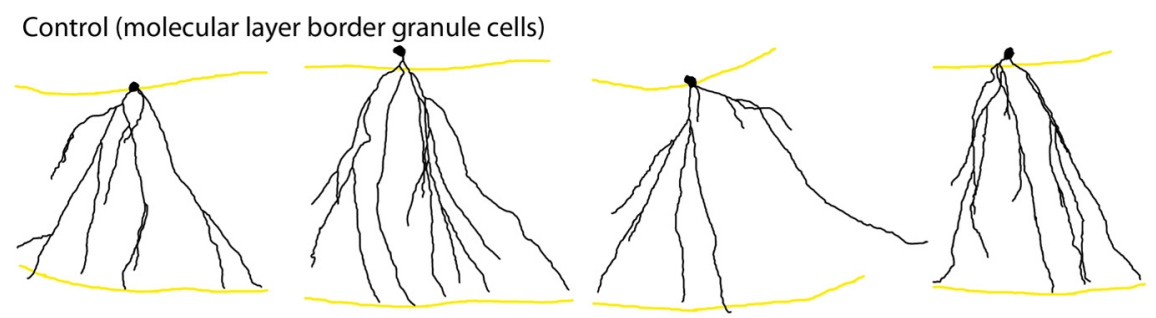

Status Epilepticus (molecular layer border granule cells)
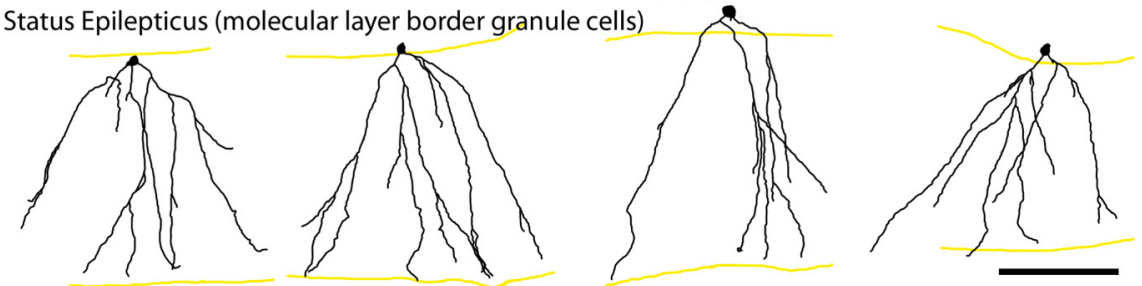

Figure 3. Neurolucida reconstructions of MLB granule cells from Thy1-GFP-expressing control animals (top) and animals treated with pilocarpine to induce status epilepticus (bottom). Black, Apical dendrites; yellow lines, molecular layer-granule cell body layer border and the hippocampal fissure. Cells from epileptic animals are grossly normal, lacking the overt structural abnormalities evident among newborn cells exposed to status. Scale bar, $100 \mu \mathrm{m}$.

normalities among cells from epileptic animals did not follow a consistent pattern; rather, they manifested primarily as a failure to develop typical fanlike apical dendritic trees, and were present equally among cells with and without basal dendrites. Cells with obvious abnormalities included three with dendrites that projected obliquely rather than directly into the molecular layer and four with collapsed, rather than spreading, apical dendritic trees. The former abnormality gave the affected cells a windswept appearance, whereas the latter cells resembled a closed parasol (Fig. 2). Both abnormalities are reminiscent of pathologies described by Scheibel and Scheibel (1973) from human epileptic material. The remaining five cells exhibited generally disorganized apical dendritic trees (Fig. 2, bottom row) and included abnormalities such as crossing dendrites (Fig. 2, blue arrow), recurrent basal dendrites (Fig. 2, blue arrowheads), a projection that exited the dentate molecular layer (Fig. 2, red arrow), and a cell with a corkscrewed primary apical dendrite (data not shown). Finally, although not included among the features scored definitively as abnormal, two cells possessed unusually large somas, giving them a hypertrophied appearance.

To confirm qualitative impressions of altered dendritic trajectory among newborn cells from epileptic animals (e.g., windswept cells), the angle of each apical dendrite initial segment was measured relative to a line drawn perpendicular to the granule cell body layer (such that greater angles reflected more oblique trajectories). Angles were significantly greater for cells from epileptic animals relative to controls [newborn control, $13.4^{\circ}\left(0.8-33.5^{\circ}\right)$; newborn SE, $21.9^{\circ}\left(1.0-87.5^{\circ}\right) ; p=0.034$, Mann-Whitney rank sum test (RST)]. Cells with the greatest angles appeared windswept.

The reduction in dendritic spread evident among cells with the closed-parasol deformation tended to increase the number of self-crossing dendritic branches (defined as dendrites that intersected in two-dimensional neuronal projections, so branches need not make physical contact to be scored as crossing). The number of crossing dendritic branches significantly increased among newborn cells exposed to SE [newborn control, 2.5 crossings/DGC (range, $0-7$ ); newborn SE, 4.0/DGC (range, $0-17$ ); $p=0.032 ; t$ test on data normalized by square root transformation]. This finding confirms qualitative impressions that the apical dendrites of newborn granule cells exposed to SE tend to overlap and project into the same region of neuropil, rather than spreading evenly throughout the molecular layer. 
Table 5. Spine density and number of newborn cells exposed to status epilepticus versus control cells

\begin{tabular}{|c|c|c|c|c|c|c|c|c|c|}
\hline & $\begin{array}{l}\text { DGC-L spine } \\
\text { density }\end{array}$ & $\begin{array}{l}\text { DGC-L spine } \\
\text { number }\end{array}$ & $\begin{array}{l}\text { IML spine } \\
\text { density }\end{array}$ & $\begin{array}{l}\text { IML spine } \\
\text { number }\end{array}$ & $\begin{array}{l}\text { MML spine } \\
\text { density }\end{array}$ & $\begin{array}{l}\text { MML spine } \\
\text { number }\end{array}$ & $\begin{array}{l}\text { OML spine } \\
\text { density }\end{array}$ & $\begin{array}{l}\text { OML spine } \\
\text { number }\end{array}$ & $\begin{array}{l}\text { Total spine } \\
\text { number }\end{array}$ \\
\hline Newborn Control & $0.4(0.1-2.4)$ & $28.5(2-165)$ & $2.0(0.8-6.0)$ & $275.8(106-1326)$ & $3.0(1.3-5.2)$ & $849.6(372-1668)$ & $2.7(0.8-6.6)$ & $583.7(67-1622)$ & $1885.7(704-4431)$ \\
\hline Newborn SE & $0.5(0.2-2.9)$ & $40.3(12-133)$ & $1.3^{*}(0.3-4.5), p=0.019$ & $185.5(24-1504)$ & $1.7^{*}(0.5-6.5), p=0.030$ & $569.8(102-3198)$ & $1.8^{*}(0.4-5.6), p=0.046$ & $328.3(52-1674)$ & $1232.5(296-6440), p=0.070$ \\
\hline
\end{tabular}

DGC-L, DGC layer; MML, middle molecular layer; 0ML, outer molecular layer. Values are medians (range). ${ }^{*} p<0.05$, Mann-Whitney RST. Significant values are in bold.

In contrast to these changes, typical measures of apical dendritic structure, including apical dendrite number, total apical dendrite length, apical dendrite length by layer, and total number of branch points, revealed similar values for both groups (Table 1). Sholl analysis, a measure of dendritic nodes and terminations by layer, also revealed no significant differences (data not shown). Since dendritic truncation could minimize any real differences in these values, however, we took the additional step of generating estimates (see Materials and Methods) to compensate for truncation effects. As with the raw data, estimated measures of total dendritic length ( $p=0.443$, RST) (Table 1) and dendritic length by layer (data not shown) were statistically similar between groups. As another means of controlling for truncation effects, we examined several parameters that tend to be less affected by artificial truncation. Specifically, dendritic branches and branch segments (first through fifth order) with intact terminations were examined. The length (apical dendrite length from the cell body to its natural ending) and terminal branch order for intact dendrites did not differ between groups (Table 2). The median length of second and third order dendritic segments, however, was significantly increased for cells exposed to status (Table 2). Together, these findings suggest a relative preservation of typical measures of dendritic structure; however, there are clearly subtle changes present, and since the impact of dendritic truncation cannot be entirely obviated, the possibility that other subtle changes remain undetected cannot be excluded.

\section{The dendritic morphology of molecular layer border dentate} granule cells is only minimally altered by status epilepticus To determine whether status epilepticus disrupts the dendritic structure of granule cells already mature at the time of the insult, BrdU-negative, GFP-expressing cells located on the granule cell layer-molecular layer border were examined. A total of $21 \mathrm{MLB}$ granule cells were selected from six control mice and 20 MLB cells were selected from six epileptic mice. In contrast to newborn granule cells exposed to status, MLB cells exposed to status were almost identical to MLB cells from control animals (Tables 3, 4). None of the gross abnormalities evident among newborn cells were present among MLB cells (Fig. 3) and evidence for somatic hypertrophy was absent (Table 3). Changes in dendritic trajec-

Control

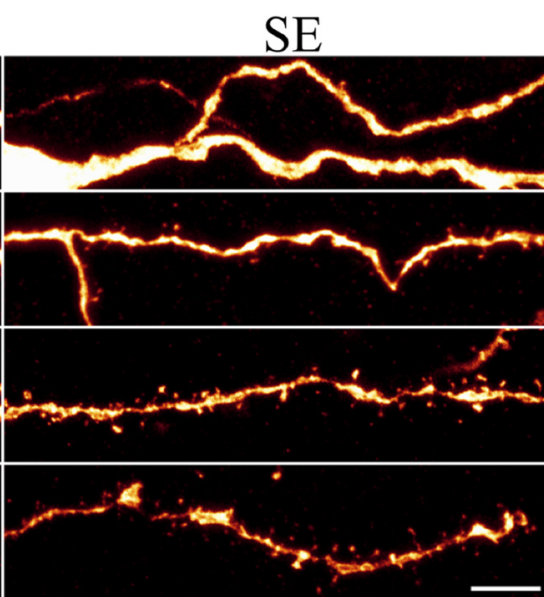

igure 4. Confocal reconstructions of dentate granule cell layer ( $\mathrm{DGCL}$ ) and IML, middle (MML), and outer (OML) molecular laye dendrites of 12-week-old BrdU-labeled, GFP-expressing granule cells from control and SE animals. Cells from epileptic animals exhibited lower spine densities in all regions except the granule cell layer. Scale bar, $5 \mu \mathrm{m}$.

A

Figure 5. Estimated spine numbers (spine density $\times$ estimated apical dendrite length) for BrdU-labeled, GFP-expressing, 12-week-old granule cells from control animals (gray bars) and epileptic animals (SE, blue bars). $\boldsymbol{A}$, Granule cells from epileptic animals exhibited significant reductions in the spine number in the IML and middle molecular layer (MML) relative to controls. $\boldsymbol{B}$ Total spine number was also significantly reduced. Box plots shows fifth and 95 th percentiles, median lines, and outliers. ${ }^{*} p<0.05$ versus control.

tory $\left[\right.$ MLB control, $37.7^{\circ}$ (range, $\left.3.9-75.9^{\circ}\right) ;$ MLB SE, $39.8^{\circ}$ (range, $\left.11.8-89.1^{\circ}\right) ; p=0.927$, Mann-Whitney RST) and crossing branches [MLB control, 3.0 crossings/DGC (range, 0-7); MLB SE, 3.0/DGC (range, $1-12$ ); $p=0.696$; $t$ test on data normalized by square root transformation] were also absent. Curiously, however, apical dendrite length to a natural ending was slightly decreased among MLB SE cells (Table 4$)(p=0.022$, rank sum test). A segment analysis revealed that first through fifth order segments were similar in control and epileptic mice, but terminal dendritic segments (which could be of any order), were significantly shorter for MLB SE cells ( $p=0.015$, rank sum test) (Table 4). Together, these findings indicate that granule cells located along the molecular layer border may exhibit a slight reduction in growth at the dendritic tips following status but, overall, their structure is relatively resistant to seizure-induced disruption. 

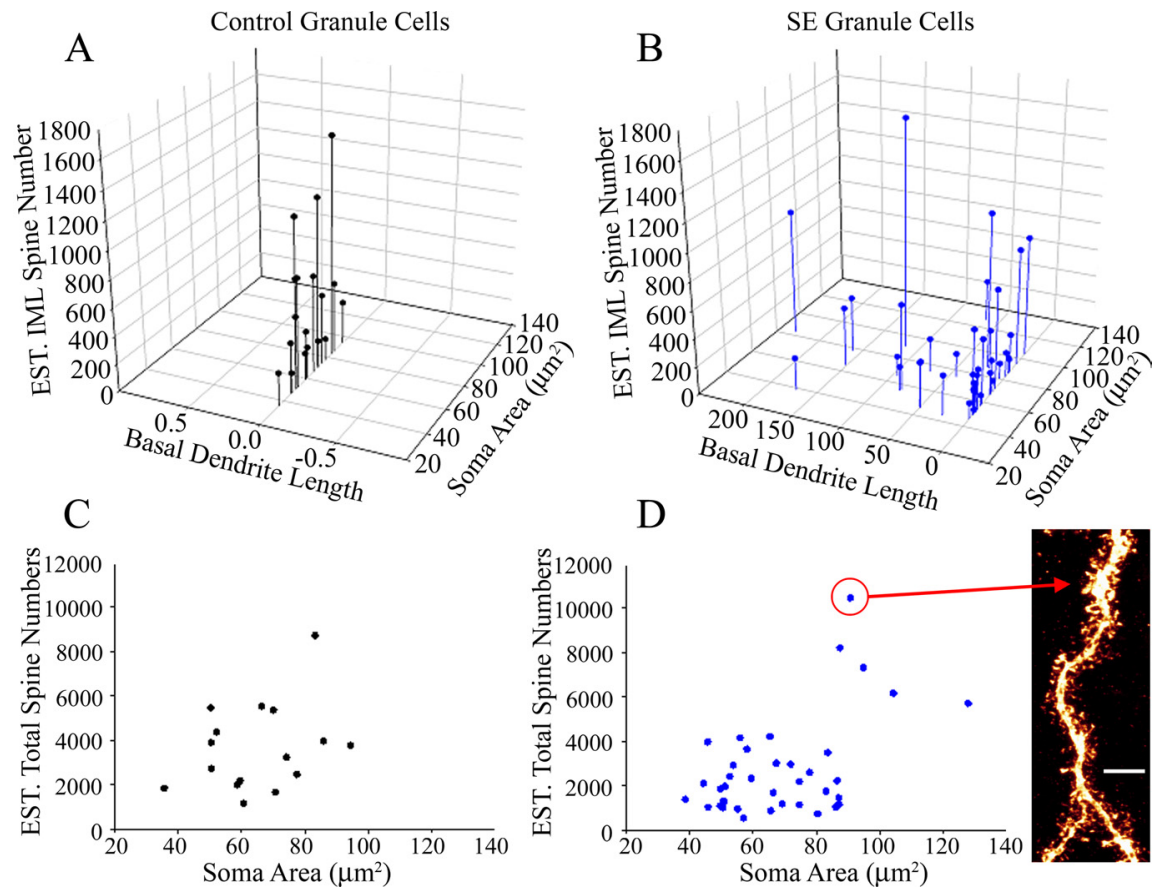

Figure 6. $\quad A, B$, Three-dimensional scatter plots showing relationships between EST.IML spine number, soma area, and basal dendrite length. For 12 -week-old granule cells from control animals $(\boldsymbol{A})$, regression analyses indicated that soma area was not predictive of spine number (and basal dendrites were absent, so all length values $=0$ ). By contrast, both soma area and basal dendrite length predicted IML spine density in epileptic animals, although, notably, the former two variables did not always cosegregate. $\boldsymbol{C}, \boldsymbol{D}$, Two-dimensional scatter plots showing the relationships between estimated total spine number and soma area indicate that the two variables are not correlated in control animals ( $p=0.548$; Spearman rank order) and that the cells tend to cluster together. Age-matched granule cells from epileptic animals, in contrast, show a significant positive correlation between soma area and total spine number ( $p=0.029$ ). The resulting pattern strongly suggests the existence of two distinct groups: the majority with low spine densities and smaller somas and the minority $(\sim 10 \%)$ with higher spine densities and larger somas. Inset, Confocal reconstruction showing a middle molecular layer segment from the highlighted cell in $\boldsymbol{D}$. This cell, from an epileptic animal, had the greatest number of spines of any cell in the study. Scale bar, $5 \mu \mathrm{m}$.

Although MLB cells were not birth-dated with BrdU, granule cells located along the molecular layer border are among the first generated during development (Schlessinger et al., 1975; Bayer, 1980a,b; Altman and Bayer, 1990a,b). It is likely, therefore, that the majority of these cells were already mature at the time of the insult. We further tested this assumption by measuring the distance between the soma of each cell and the hilar border. The outside-in layering pattern of the dentate places the oldest cells close to the molecular layer border and the youngest cells next to the hilar border. There was almost no positional overlap between the somas of birth-dated newborn granule cells and MLB cells ( $p<0.001$ for both MLB groups vs both newborn groups, ANOVA) (supplemental Tables 1, 2, available at www.jneurosci. org as supplemental material). Thus, although the exact age of MLB cells was not determined, they clearly represent a distinct cell population likely generated around embryonic day 15 (Mathews et al., 2010).

Newborn granule cells in the epileptic brain have fewer spines Dendritic spine density was measured along dendritic segments located within the dentate granule cell layer and the inner, middle, and outer molecular layers (control, $n=16$ cells; SE, $n=38$ ), providing a means to assess relative numbers of excitatory synaptic inputs to the apical dendritic trees of these newly generated cells (Trommald and Hulleberg, 1997). In the case of the epileptic brain, changes in the granule cell layer and the inner molecular layer are of particular interest, as these regions are targeted by sprouted mossy fiber axons. Spine density was significantly lower in all three regions of the molecular layer for granule cells exposed to status epilepticus relative to controls (Table 5; Fig. 4). The density of spines in the granule cell layer was unchanged. Since the dendritic trees of these cells were reconstructed, it was also possible to determine the total number of spines present on a cell in each layer (spine density per layer $X$ apical dendrite length in that layer). Spine number was determined using both raw length data and estimated length data (compensating for the number and position of dendritic truncations). Although counts generated using the former approach did not differ significantly (Table 5), significant reductions in spine number were evident in the inner $(p=0.035, \mathrm{RST})$ and middle $(p=0.035$, RST) molecular layers using the latter approach (Fig. 5A). Estimated total spine number was also reduced for cells from epileptic animals relative to controls ( $p=$ 0.033 , RST) (Fig. $5 B$ ). These findings suggest that input to newborn granule cells is reduced in the epileptic brain.

\section{Molecular layer border granule cells exhibit reduced spine density after status}

To determine whether MLB granule cells exhibit similar or disparate patterns of spine loss in the same animals, inner molecular layer spine density was quantified along dendritic segments belonging to cells from this population. In the inner molecular layer, MLB cells from epileptic animals $(n=33)$ exhibited reductions in spine density relative to MLB cells from control animals $(n=20)$, suggesting that both newborn and mature granule cells respond similarly to status epilepticus with regard to inner molecular layer spine changes (MLB control, $2.2 \pm 0.2$ spines/ $\mu \mathrm{m}$; MLB SE, $1.4 \pm$ 0.1 spines $/ \mu \mathrm{m} ; p<0.001, t$ test $)$.

\section{Spine number among newborn granule cells exposed to status} is highly variable

Interestingly, whereas the majority of newborn granule cells exposed to status displayed reductions in spine density and number, the range was quite large and substantially overlapped the control population (Fig. 5). Gross observations supported this impression, with some newborn cells appearing almost aspiny and others coated with spines. This was true even for cells from the same epileptic animal, suggesting that inter-animal differences in seizure severity are unlikely to account for the variability.

Since high spine densities could be indicative of cellular hyperexcitability, we were quite intrigued by this subpopulation. Therefore, we queried whether cells with large numbers of spines exhibited other abnormal traits that might suggest a role in epileptogenesis. Qualitative observations were ambiguous. Both morphologically normal and abnormal cells exhibited high spine numbers (Fig. 2, asterisks). A more quantitative approach using a forward stepwise regression was thus conducted to systematically identify traits predictive of high spine density and number. The 
regression analysis used the dendritic measurements that differed between cells from control and epileptic animals, including basal dendrite length, primary dendrite trajectory, and number of crossing branches. In addition, soma area was included based on qualitative findings of a somatic hypertrophy. Regression analyses focused on inner molecular layer (IML) spine density and number, as this is the region targeted by sprouted mossy fiber axons. This approach identified basal dendrite length ( $p=$ $0.025)$ and soma area $(p<0.041)$ as key variables predicting inner molecular layer spine density, with cells having long basal dendrites and large somas tending toward greater spine density. A similar approach was used to determine which traits were predictive of spine numbers, although in this case, crossing branch number was normalized by dividing by total dendrite length (since spine number and crossing branch number are both dependent on dendrite length, the two values would automatically be correlated otherwise). Both soma area $(p=0.019)$ and basal dendrite length $(p=0.047)$ were predictive of inner molecular layer spine numbers (Fig. $6 \mathrm{~B}$ ), whereas only soma area was predictive of total spine numbers $(p=0.002)$ (Fig. 6D) among neurons from epileptic animals. In contrast to these findings, none of the traits examined predicted spine density or number for control cells (Fig. 6A,C).

Given that longer basal dendrites predict a greater spine number, we subdivided the cells from epileptic animals into groups with and without basal dendrites and queried whether spine values (generated using length estimates) for the two subgroups differed significantly. Interestingly, cells with basal dendrites (BD) had significantly more spines in the granule cell body layer [no BD, 37.5 (range, 12-133); $\mathrm{BD}, 64.0$ (range, 18-132); $p=$ 0.045]. Inner molecular layer values, on the other hand, did not differ significantly [IML, no BD, 213 (range, 28-836); BD, 287 (range, 98-1504)]. We interpreted this negative result cautiously, however, since the regression analyses only found basal dendrite length - not the presence of a basal dendrite per se-to be predictive.

\section{Gli1-CreER ${ }^{\mathrm{T} 2} \times$ GFP reporter double-transgenic mice}

To further explore the association between spine density and basal dendrites, and to confirm and quantify the level of somatic hypertrophy among newborn cells, we used a conditional, inducible, bitransgenic mouse model that provides improved yields of newborn granule cells for study. This new approach used Gli1$\mathrm{CreER}^{\mathrm{T} 2} \times$ GFP reporter mice to fate-map adult-generated granule cells.

\section{Fate-mapped newborn granule cells exhibit dendritic} abnormalities and somatic hypertrophy

Gli1-CreER ${ }^{\mathrm{T} 2} \times$ GFP-expressing bitransgenic mice were dosed with tamoxifen following pilocarpine or control treatment to persistently label Gli1-expressing granule cell progenitors and all their progeny with GFP. Although labeled progenitors could conceivably generate new cells throughout the 3 month survival period, morphologically immature granule cells were excluded from the study (see Materials and Methods), so the cells examined here were likely born 0-2 months after status. Consistent with this interpretation, cells from Gli1 mice were qualitatively similar to the 3-month-old cells labeled in the Thy1-GFPexpressing animals. Moreover, whereas cells from control Gli1 animals possessed normal morphologies (Fig. 7A), cells from epileptic animals exhibited all the key abnormalities described in the present and previous works, including ectopic granule cells, granule cells with basal dendrites, and granule cells with wind-
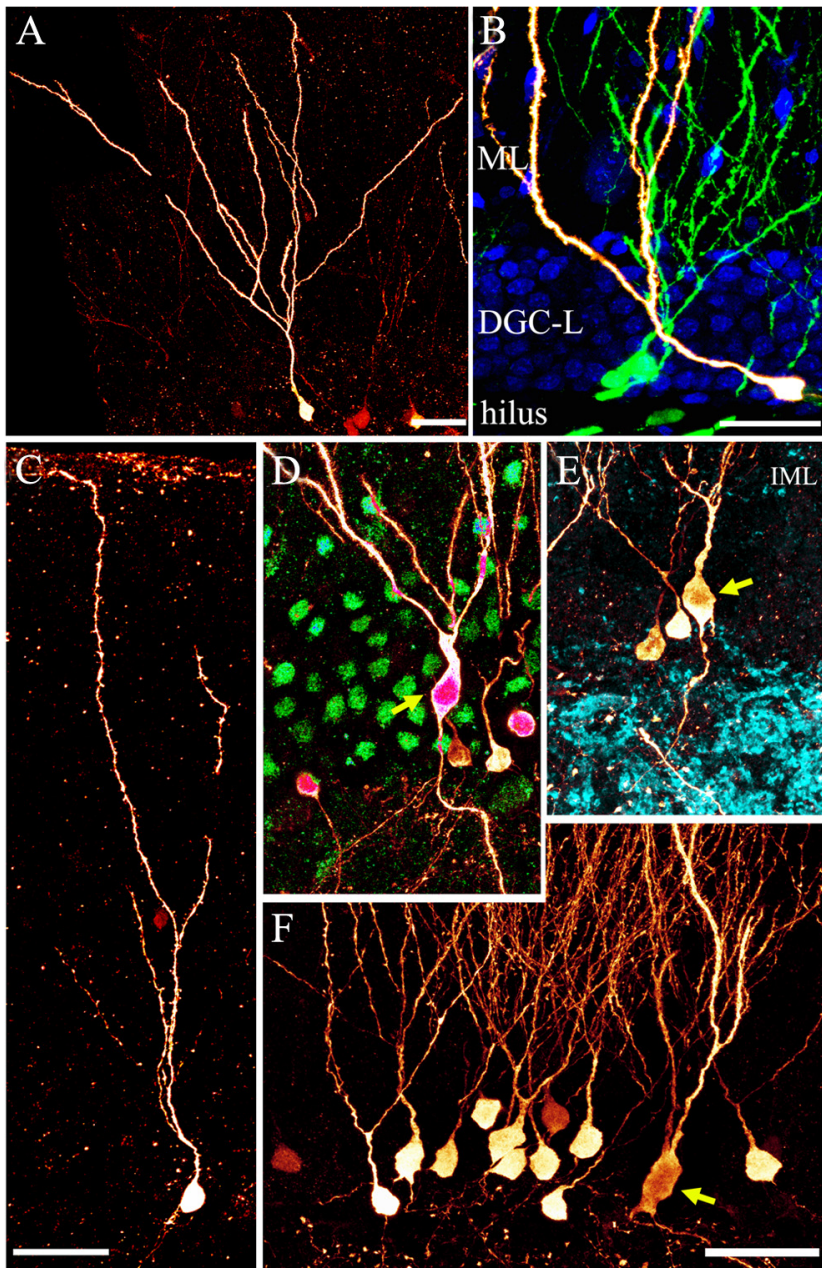

Figure 7. A-F, Confocal reconstructions of GFP-expressing newborn granule cells from Gli1CreER ${ }^{\mathrm{T} 2} \times$ GFP reporter mice. $A$, Confocal reconstruction of a newly generated granule cell from a control animal with typical apical dendritic structure. $\boldsymbol{B}$, Reconstruction of a windswept GFPexpressing granule cell (orange) from an epileptic animal. Adjacent GFP-expressing granule cells are shown in green, whereas Nissl staining is shown in blue. $\boldsymbol{C}$, Newly generated granule cell from an epileptic animal exhibiting the closed parasol deformation. $\boldsymbol{D}$, Hypertrophied granule cell (arrow) from an epileptic animal coimmunostained with GFP (orange) and the granule cell-specific marker Prox1 (pink). The two unlabeled granule cells expressed Prox1 in a focal plane not included in the image composite for clarity. Granule cells singly labeled for Prox1 are shown in green. $E$, Coimmunostaining with GFP and ZnT3 (cyan) showing a hypertrophied granule cell (arrow) and two typically sized neighbors. $\boldsymbol{F}$, Example of numerous typically sized granule cells adjacent to a hypertrophied granule cell (arrow). DCG-L, Dentate granule cell layer; $\mathrm{ML}$, molecular layer. Scale bars, $30 \mu \mathrm{m}$.

swept, collapsed, and disorganized dendritic trees (Fig. $7 B, C$ ). Numerous striking examples of hypertrophied granule cells, with enlarged somas and thick proximal dendrites, were also observed in epileptic mice (Fig. 7D-F). To quantify this effect, the somatic area of 101 cells from control animals and 94 cells from epileptic animals was determined. Mean areas \pm SD for control and epileptic cells were $63.6 \pm 12.5$ and $67 \pm 17.3 \mu \mathrm{m}^{2}$, respectively. For each group, granule cells with soma areas 2 SDs or greater above the control mean were defined as hypertrophied. In the epileptic group, $14 \%$ of cells met this criterion, whereas only $4 \%$ of cells were this large in controls. This difference was significant $(p=$ $\left.0.029, \chi^{2}\right)$, confirming qualitative impressions from the BrdUlabeled, Thy1-GFP mice that a subset of newborn cells in epileptic animals are hypertrophied. Finally, although there was no evidence that any neuron types other than granule cells expressed GFP in the hippocampus of Gli1-CreER ${ }^{\mathrm{T} 2}$ mice, these hypertro- 

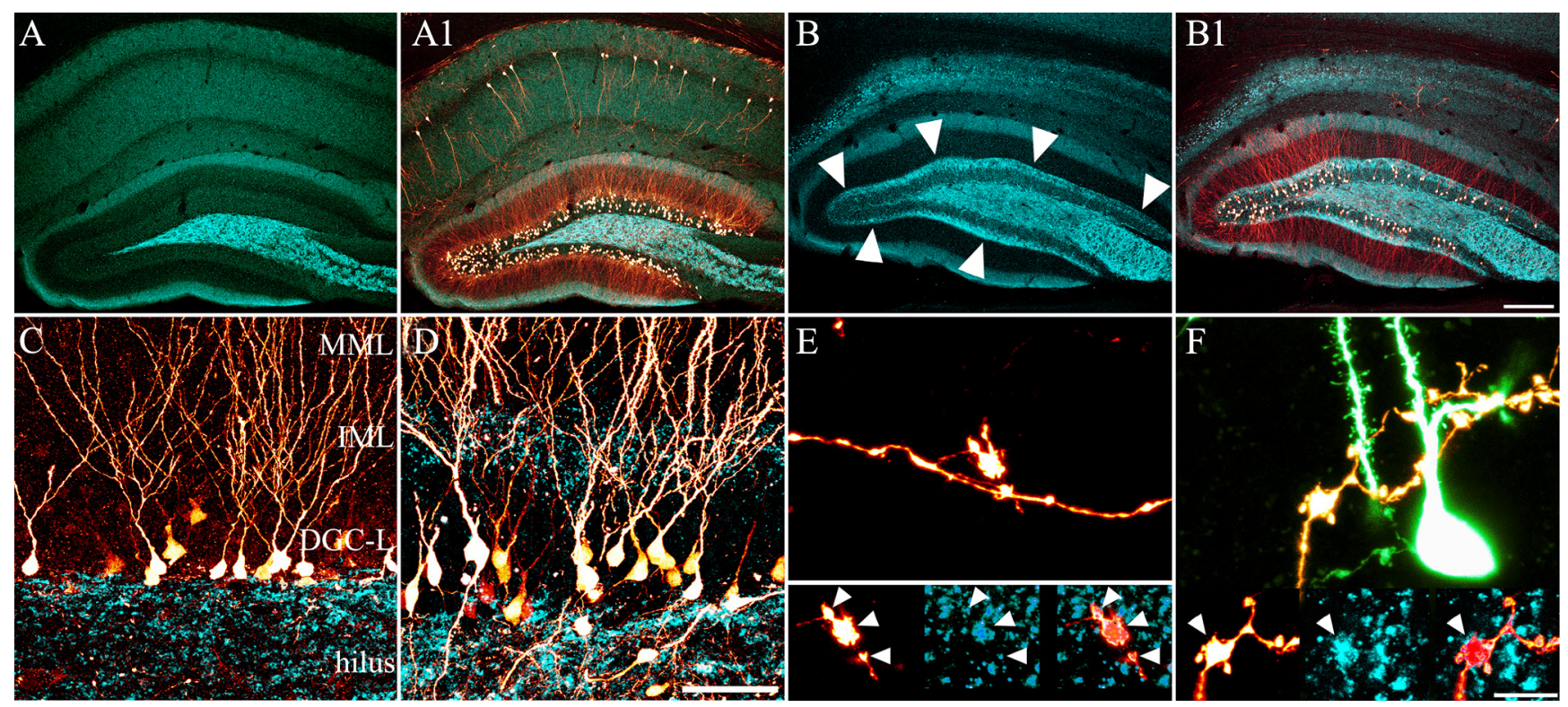

Figure 8. A, Hippocampus from a control Thy1-GFP-expressing mouse coimmunostained for ZnT-3 (A), which reveals mossy fiber terminals, and GFP (merged images, $A .1$ ). In control animals, ZnT-3 staining is most prominent in the mossy fiber pathway (hilus and stratum lucidum). $\boldsymbol{B}, \boldsymbol{B} .1$, Three months after status epilepticus, staining is also present in the inner molecular layer, indicative of mossy fiber sprouting ( $\boldsymbol{B}$, arrowheads). $\boldsymbol{C}$, Control Gli1-CreER ${ }^{\mathrm{T}} \times$ GFP reporter mouse coimmunostained with GFP and ZnT-3. Newly generated granule cells exhibit typical morphology and positioning, and mossy fiber sprouting is absent. Layer denotations in Capply to $\boldsymbol{D}$ as well. MML, Middle molecular layer; DGC-L, dentate granule cell layer. $\boldsymbol{D}$, Epileptic Gli1-CreER ${ }^{T 2} \times$ GFP reporter $^{2}$ mouse showing GFP-expressing granule cells generated after status. Note the appearance of cells with basal dendrites and ectopically located somata. ZnT-3 labeling further reveals mossy fiber sprouting in the inner molecular layer. $\boldsymbol{E}, \boldsymbol{F}$, Examples of sprouted mossy fiber axons with terminals in the IML. Insets show double-labeling of the terminals with ZnT-3. Scale bars: $\boldsymbol{A}, \boldsymbol{B}, 200 \mu \mathrm{m} ; \boldsymbol{C}$ $D, 60 \mu \mathrm{m} ; E, F, 10 \mu \mathrm{m}$.

phied cells so dwarfed their neighbors that we colabeled some of the more impressive examples with the granule cell-specific marker Prox1 (Fig. 7D), confirming their identity as granule cells.

Newborn granule cells with long basal dendrites have more spines and receive more recurrent input than adjacent newborn cells without basal dendrites

We next queried whether newborn cells with basal dendrites exhibited greater spine density and number in the inner molecular layer relative to adjacent newborn cells lacking basal dendrites. In contrast to studies with Thyl-GFP mice, however, only granule cells with basal dendrites projecting at least halfway across the hilus were included to specifically address the question as to whether cells with long basal dendrites possess more spines. In addition, spines were assessed to determine whether or not they were apposed to puncta immunoreactive for ZnT-3. Previous studies have demonstrated that ZnT-3 antibodies label mossy fiber terminals with high specificity (McAuliffe et al., 2010), and immunostaining of control and epileptic mice confirmed the utility of this antibody for revealing mossy fiber sprouting grossly and at the level of individual mossy fiber terminals (Fig. 8). Spines apposed to ZnT-3-immunoreactive puncta (Fig. 9), therefore, are likely receiving mossy fiber input.

In epileptic Gli1 mice, inner molecular layer spine density was significantly lower among newborn granule cells lacking basal dendrites (no BD, $n=10$ ) relative to cells from control animals $(n=10)$. Critically, however, cells lacking basal dendrites also differed significantly from neighboring newborn granule cells $(\mathrm{BD}+, n=10)$ with basal dendrites [control, 3.3 (range, 2.36.6); no $\mathrm{BD}, 1.8$ (range, 1.2-2.8); $\mathrm{BD}+, 3.4$ (range, 2.1-8.1); Kruskal-Wallis ANOVA on ranks, $p<0.001$ ]. Similarly, inner molecular layer spine number (IML spine density $\times$ EST.IML dendrite length) was reduced for cells lacking basal dendrites relative to neighboring cells with basal dendrites and to cells from control animals (Kruskal-Wallis, $p=0.004$ ) (Fig. 10A). These findings confirm the prediction from Thyl-GFP-based regression data (Fig. $6 \mathrm{~B}$ ) that cells with long basal dendrites will have more spines than cells lacking basal dendrites.

Finally, the number of spines apposed to ZnT-3-immunoreactive puncta was determined for each group to assess the degree of recurrent mossy fiber innervation. Whereas ZnT-3apposed spines were almost nonexistent in control animals, nearly half of the spines on newborn cells from epileptic animals were apposed to immunoreactive puncta. Moreover, although the proportion of spines apposed to ZnT-3-immunoreactive puncta was similar for cells from epileptic animals with and without basal dendrites (48 and 45\%, respectively), since cells with basal dendrites possessed more than twice the total spines, their net input from ZnT-3-positive puncta was significantly greater (ANOVA on ranked data with Holm-Sidak posttest, $p<0.001$ ) (Fig. 10B).

\section{Discussion}

Aberrant integration of adult-generated granule cells has been proposed to contribute to the development of epilepsy. This hypothesis, however, is not universally accepted, in light of important findings indicating that newborn cells may protect the brain from excess excitability (Jakubs et al., 2006). Here, we explore the idea that conflicting findings may reflect heterogeneity among newborn granule cells in the epileptic brain. To test this hypothesis, we characterized the morphology of adult-generated granule cells maturing in either control or epileptic animals. This approach produced several major findings. First, significant numbers of newborn granule cells from epileptic animals exhibited grossly abnormal apical dendritic trees, indicating that abnormalities evident in structure and growth rates among 2- to 4-week-old cells (Heinrich et al., 2006; Overstreet-Wadiche et al., 2006; Arisi and Garcia-Cairasco, 2007; Shapiro et al., 2007) lead 
to permanent distortions in neuronal morphology. In contrast, MLB granule cells, likely born months before the insult, showed only slight reductions in growth at the dendritic tips. Growth in distal regions of the dendritic tree has been observed following exercise (Eadie et al., 2005) and the present findings imply that this type of plasticity may be disrupted among mature cells in epilepsy but, importantly, gross abnormalities were absent. These findings increase the likelihood that grossly abnormal granule cells observed in human epilepsy are adult-generated (Scheibel and Scheibel, 1973; Franck et al., 1995; von Campe et al., 1997). Second, status epilepticus led to a reduction in spine density among the majority of adult-generated granule cells exposed to status early in their development. Approximately $10 \%$ of newborn granule cells, however, possessed large numbers of spines, with a few cells exceeding even the spiniest cells in controls (Fig. 6B,D). Moreover, cells with the most spines tended to either have long basal dendrites, large somas, or both. Third, studies using bitransgenic mice confirmed a shift toward somatic hypertrophy among a subset of new cells. Again, $\sim 10 \%$ of newborn granule cells were affected. Fourth, cells with long basal dendrites were shown to have significantly more contact with sprouted mossy fiber axons, relative both to newborn granule cells from control animals and to adjacent newborn granule cells lacking basal dendrites. Together, these studies demonstrate a striking heterogeneity among newborn granule cells in the epileptic brain, suggesting that new cells_- even cells similar in position and age-could play very different roles in the epileptogenic process.

\section{Complex roles for adult-generated granule cells in the development of epilepsy}

A role for adult-generated granule cells in epileptogenesis was first proposed by Parent and Lowenstein (2002) and is the subject of numerous reviews (Shapiro et al., 2008; Kuruba et al., 2009; Scharfman and McCloskey, 2009). Briefly, morphological studies demonstrate that granule cells born up to 5 weeks before and up to 8 weeks after an epileptogenic insult underlie much of the recurrent excitatory circuitry established within the epileptic dentate gyrus, including hilar ectopic granule cells (Parent et al., 2006), granule cells with basal dendrites (Jessberger et al., 2007; Walter et al., 2007), and granule cells exhibiting mossy fiber sprouting (Parent et al., 1997; Jessberger et al., 2007; Danzer, 2008; Kron et al., 2010). Despite this prominent role in the pathology of the epileptic dentate, however, attempts to prevent epileptogenesis by reducing neurogenesis have produced mixed results, with studies showing either no (Radley and Jacobs, 2003; Pekcec et al., 2007; Pekcec et al., 2008; Pekcec et al., 2010) or only partial efficacy (Jung et al., 2004, 2006; Sugaya et al., 2010). Moreover, newborn cells that follow the correct migration pattern to the cell body layer have been shown to be less excitable in epileptic animals relative to controls (Jakubs et al., 2006). Although hilar ectopic granule cells, which migrate the wrong direction into the hilus, do exhibit hyperexcitability (Scharfman et al.,
A
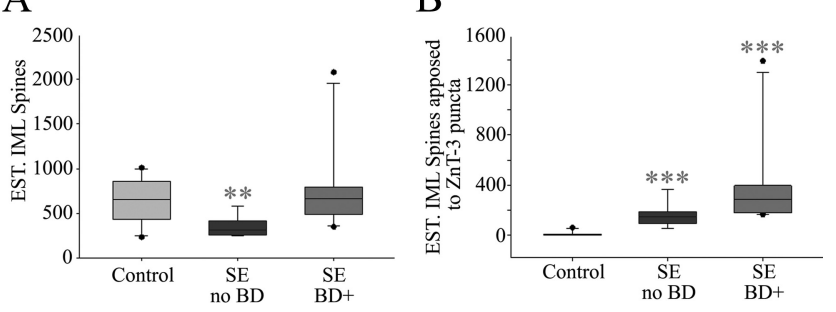

Figure 10. A, EST.IML spines possessed by GFP-expressing newborn granule cells from control and epileptic Gli1-CreER ${ }^{\mathrm{T} 2} \times$ GFP-expressing mice treated with tamoxifen 3 months earlier. For epileptic animals (SE), cells were further subdivided into those with $(B D+)$ and without (no BD) basal dendrites. Spine density was significantly reduced for cells lacking basal dendrites relative to all other groups, and cells with long basal dendrites were statistically equivalent to controls. ${ }^{* *} p<0.01$ relative to all other groups. $\boldsymbol{B}$, Cells lacking basal dendrites possessed significantly more ZnT-3-apposed spines relative to control cells, and cells with basal dendrites had significantly more spines relative to all other groups. ${ }^{* * *} p<0.001$ relative to all other groups.

2000), most newborn cells migrate to the cell body layer (Walter et al., 2007), leading to the suggestion that the majority of new cells might actually be protective (Kempermann, 2006; Parent and Murphy, 2008).

The present work, however, demonstrates a surprising complexity among newly generated cells correctly located in the cell body layer. The majority of new cells possessed few dendritic spines, suggesting they are minimally innervated-a conclusion consistent with the physiological data indicating that newborn cells are less excitable (Jakubs et al., 2006). Approximately 10\% of newborn cells examined here, however, possessed a large number of spines, suggesting robust afferent input. Given the small percentage of cells exhibiting this morphological phenotype, however, it is likely that they are poorly represented in physiological 
studies. Since not all spines possess functional synapses, and not all synapses occur at spines, physiological studies of these cells will be needed to confirm predictions of robust innervation.

\section{Newborn granule cells with large somas, long basal dendrites, and abundant spines}

A goal of the present study was to begin to elucidate which newborn granule cells might be most likely to participate in epileptogenesis. This question is important, since determining the role of newborn cells in epilepsy could depend critically on which new cells are examined.

Recurrent excitatory input is hypothesized to play an important role in epileptogenesis (Sutula et al., 1988; Sutula and Dudek, 2007), so cells receiving more recurrent input would be predicted to play a greater role in epilepsy. For cells correctly positioned in the granule cell body layer, two mechanisms support de novo recurrent circuit formation during epileptogenesis: mossy fiber sprouting into the inner molecular layer and basal dendrite formation. Mossy fiber sprouting is robust and widespread (Nadler, 2003) and, at least in principle, could involve all granule cells. Granule cells with basal dendrites also receive recurrent input following innervation by hilar mossy fiber axons (Austin and Buckmaster, 2004; Thind et al., 2008); however, in this case, only cells with basal dendrites are involved. In the present study, all newborn cells examined in epileptic animals appeared to receive some recurrent input through sprouted mossy fiber axons in the inner molecular layer. Cells with long basal dendrites, however, received twice the input of cells lacking basal dendrites (Fig. $10 \mathrm{~B}$ ). Although the combined effect of recurrent input through apical and basal dendrites is not clear, the finding is intriguing as it demonstrates that recurrent input within the inner molecular layer is not equally distributed among granule cells. Some cells receive more. Finally, with regard to basal dendrites, it is notable that only long basal dendrites were predictive of increased spine density. We found many examples of cells with shorter basal dendrites that possessed few apical spines, so the mere presence of a basal dendrite is not a reliable indicator of a highly innervated cell. Conversely, not all cells with large numbers of spines possessed basal dendrites (two of the five spiniest cells had no basal dendrites), so although the association between basal dendrite length and spine density was significant, basal dendrites are not a requirement for a spiny cell.

Perforant path input from entorhinal cortex is also implicated in epileptogenesis (Behr et al., 1998; Hsu, 2007), so it follows that cells with robust perforant path input might be more likely to play a role in epileptogenesis. Middle and outer molecular layer spine numbers provide an indication of perforant path input and, in the present study, the five cells with large numbers of inner molecular layer spines (Fig. $6 B$ ) were similarly decorated in the middle and outer molecular layers (Fig. 6D). These cells, therefore, might reasonably be deemed the most likely to play a role in epileptogenesis. Given the relatively infrequent nature of these cells, testing this idea with physiological studies could prove challenging; thus it is noteworthy that these granule cells tended to have particularly large somas. This feature might prove a useful aid for future studies aimed at identifying and recording from these cells.

In summary, the present study demonstrates significant heterogeneity among newly generated granule cells in the epileptic brain. A majority of new cells possessed fewer dendritic spines, consistent with speculation that these cells may act to reduce excitability in the epileptic brain. On the other hand, most of these new cells also appear to be innervated by sprouted mossy fiber axons, indicating that they are being incorporated into the recurrent circuitry of the epileptic brain. The net effect of these changes is unclear. Finally, a minority of new cells did not present with fewer spines, instead exhibiting large somas, thick apical dendrites, frequent large basal dendrites (Fig. $7 D-F$ ), and impressive accumulations of spines (Fig. $6 F$ ). These unusual, adultgenerated cells have not been previously described and likely receive robust afferent and recurrent input. Whether their outputs are equally dense, however, is not known, and indeed, until physiological studies can be conducted, the true role of these cells remains uncertain. Nonetheless, establishing the role of these hypertrophied newborn granule cells will clearly be an important avenue to pursue in future studies.

\section{References}

Ahn S, Joyner AL (2004) Dynamic changes in the response of cells to positive hedgehog signaling during mouse limb patterning. Cell 118:505-516.

Ahn S, Joyner AL (2005) In vivo analysis of quiescent adult neural stem cells responding to Sonic hedgehog. Nature 437:894-897.

Altman J, Bayer SA (1990a) Mosaic organization of the hippocampal neuroepithelium and the multiple germinal sources of dentate granule cells. J Comp Neurol 301:325-342.

Altman J, Bayer SA (1990b) Migration and distribution of two populations of hippocampal granule cell precursors during the perinatal and postnatal periods. J Comp Neurol 301:365-381.

Ambrogini P, Lattanzi D, Ciuffoli S, Agostini D, Bertini L, Stocchi V, Santi S, Cuppini R (2004) Morpho-functional characterization of neuronal cells at different stages of maturation in granule cell layer of adult rat dentate gyrus. Brain Res 1017:21-31.

Arisi GM, Garcia-Cairasco N (2007) Doublecortin-positive newly born granule cells of hippocampus have abnormal apical dendritic morphology in the pilocarpine model of temporal lobe epilepsy. Brain Res 1165:126-134.

Austin JE, Buckmaster PS (2004) Recurrent excitation of granule cells with basal dendrites and low interneuron density and inhibitory postsynaptic current frequency in the dentate gyrus of macaque monkeys. J Comp Neurol 476:205-218.

Bayer SA (1980a) Development of the hippocampal region in the rat. I. Neurogenesis examined with ${ }^{3} \mathrm{H}$-thymidine autoradiography. J Comp Neurol 190:87-114.

Bayer SA (1980b) Development of the hippocampal region in the rat. II. Morphogenesis during embryonic and early postnatal life. J Comp Neurol 190:115-134.

Behr J, Lyson KJ, Mody I (1998) Enhanced propagation of epileptiform activity through the kindled dentate gyrus. J Neurophysiol 79:1726-1732.

Claiborne BJ, Amaral DG, Cowan WM (1990) Quantitative, threedimensional analysis of granule cell dendrites in the rat dentate gyrus. J Comp Neurol 302:206-219.

Danzer SC (2008) Neuronal plasticity in the young and aged epileptic brain. Neuroscientist 14:446-458.

Danzer SC, Pan E, Nef S, Parada LF, McNamara JO (2004) Altered regulation of BDNF protein in hippocampus following slice preparation. Neuroscience 126:859-869.

Danzer SC, Kotloski RJ, Walter C, Hughes M, McNamara JO (2008) Altered morphology of hippocampal dentate granule cell presynaptic and postsynaptic terminals following conditional deletion of TrkB. Hippocampus 18:668-678.

Dashtipour K, Yan XX, Dinh TT, Okazaki MM, Nadler JV, Ribak CE (2002) Quantitative and morphological analysis of dentate granule cells with recurrent basal dendrites from normal and epileptic rats. Hippocampus 12:235-244.

Deller T, Drakew A, Frotscher M (1999) Different primary target cells are important for fiber lamination in the fascia dentata: a lesson from reeler mutant mice. Exp Neurol 156:239-253.

Eadie BD, Redila VA, Christie BR (2005) Voluntary exercise alters the cytoarchitecture of the adult dentate gyrus by increasing cellular proliferation, dendritic complexity, and spine density. J Comp Neurol 486:39-47.

Espósito MS, Piatti VC, Laplagne DA, Morgenstern NA, Ferrari CC, Pitossi FJ, Schinder AF (2005) Neuronal differentiation in the adult hippocampus recapitulates embryonic development. J Neurosci 25:10074-10086. 
Feng G, Mellor RH, Bernstein M, Keller-Peck C, Nguyen QT, Wallace M, Nerbonne JM, Lichtman JW, Sanes JR (2000) Imaging neuronal subsets in transgenic mice expressing multiple spectral variants of GFP. Neuron 28:41-51.

Franck JE, Pokorny J, Kunkel DD, Schwartzkroin PA (1995) Physiologic and morphologic characteristics of granule cell circuitry in human epileptic hippocampus. Epilepsia 36:543-558.

Heinrich C, Nitta N, Flubacher A, Müller M, Fahrner A, Kirsch M, Freiman T, Suzuki F, Depaulis A, Frotscher M, Haas CA (2006) Reelin deficiency and displacement of mature neurons, but not neurogenesis, underlie the formation of granule cell dispersion in the epileptic hippocampus. J Neurosci 26:4701-4713.

Hsu D (2007) The dentate gyrus as a filter or gate: a look back and a look ahead. Prog Brain Res 163:601-613.

Jakubs K, Nanobashvili A, Bonde S, Ekdahl CT, Kokaia Z, Kokaia M, Lindvall O (2006) Environment matters: synaptic properties of neurons born in the epileptic adult brain develop to reduce excitability. Neuron 52:1047-1059.

Jessberger S, Zhao C, Toni N, Clemenson GD Jr, Li Y, Gage FH (2007) Seizure-associated, aberrant neurogenesis in adult rats characterized with retrovirus-mediated cell labeling. J Neurosci 27:9400-9407.

Jones SP, Rahimi O, O’Boyle MP, Diaz DL, Claiborne BJ (2003) (2003) Maturation of granule cell dendrites after mossy fiber arrival in hippocampal field CA3. Hippocampus 13:413-427.

Jung KH, Chu K, Kim M, Jeong SW, Song YM, Lee ST, Kim JY, Lee SK, Roh JK (2004) Continuous cytosine- $\beta$-D-arabinofuranoside infusion reduces ectopic granule cells in adult rat hippocampus with attenuation of spontaneous recurrent seizures following pilocarpine-induced status epilepticus. Eur J Neurosci 19:3219-3226.

Jung KH, Chu K, Lee ST, Kim J, Sinn DI, Kim JM, Park DK, Lee JJ, Kim SU, Kim M, Lee SK, Roh JK (2006) Cyclooxygenase-2 inhibitor, celecoxib, inhibits the altered hippocampal neurogenesis with attenuation of spontaneous recurrent seizures following pilocarpine-induced status epilepticus. Neurobiol Dis 23:237-246.

Kempermann G (2006) They are not too excited: the possible role of adultborn neurons in epilepsy. Neuron 52:935-937.

Kron MM, Zhang H, Parent JM (2010) The developmental stage of dentate granule cells dictates their contribution to seizure-induced plasticity. J Neurosci 30:2051-2059.

Kuruba R, Hattiangady B, Shetty AK (2009) Hippocampal neurogenesis and neural stem cells in temporal lobe epilepsy. Epilepsy Behav [Suppl 1] 1:65-73.

Laplagne DA, Espósito MS, Piatti VC, Morgenstern NA, Zhao C, van Praag H, Gage FH, Schinder AF (2006) Functional convergence of neurons generated in the developing and adult hippocampus. PLoS Biol 4:e409.

Markakis EA, Gage FH (1999) Adult-generated neurons in the dentate gyrus send axonal projections to field CA3 and are surrounded by synaptic vesicles. J Comp Neurol 406:449-460.

Mathews EA, Morgenstern NA, Piatti VC, Zhao C, Jessberger S, Schinder AF, Gage FH (2010) A distinctive layering pattern of mouse dentate granule cells is generated by developmental and adult neurogenesis. J Comp Neurol 518:4479-4490.

McAuliffe JJ, Bronson SL, Hester MS, Murphy BL, Dahlquist-Topalá R, Richards DA, Danzer SC (2010) Altered patterning of dentate granule cell mossy fiber inputs onto CA3 pyramidal cells in limbic epilepsy. Hippocampus. Advance online publication. Retrieved May 27, 2010. doi:10.1002/hipo.20726.

McCloskey DP, Hintz TM, Pierce JP, Scharfman HE (2006) Stereological methods reveal the robust size and stability of ectopic hilar granule cells after pilocarpine-induced status epilepticus in the adult rat. Eur J Neurosci 24:2203-2210.

Nadler JV (2003) The recurrent mossy fiber pathway of the epileptic brain. Neurochem Res 28:1649-1658.

Nakamura T, Colbert MC, Robbins J (2006) Neural crest cells retain multipotential characteristics in the developing valves and label the cardiac conduction system. Circ Res 98:1547-1554.

Overstreet LS, Hentges ST, Bumaschny VF, de Souza FS, Smart JL, Santangelo AM, Low MJ, Westbrook GL, Rubinstein M (2004) A transgenic marker for newly born granule cells in dentate gyrus. J Neurosci 24:3251-3259.

Overstreet-Wadiche LS, Bromberg DA, Bensen AL, Westbrook GL (2006) Seizures accelerate functional integration of adult-generated granule cells. J Neurosci 26:4095-4103.
Parent JM (2007) Adult neurogenesis in the intact and epileptic dentate gyrus. Prog Brain Res 163:529-540.

Parent JM, Lowenstein DH (2002) Seizure-induced neurogenesis: are more new neurons good for an adult brain? Prog Brain Res 135:121-131.

Parent JM, Murphy GG (2008) Mechanisms and functional significance of aberrant seizure-induced hippocampal neurogenesis. Epilepsia [Suppl 5] 49:19-25.

Parent JM, Yu TW, Leibowitz RT, Geschwind DH, Sloviter RS, Lowenstein DH (1997) Dentate granule cell neurogenesis is increased by seizures and contributes to aberrant network reorganization in the adult rat hippocampus. J Neurosci 17:3727-3738.

Parent JM, Elliott RC, Pleasure SJ, Barbaro NM, Lowenstein DH (2006) Aberrant seizure-induced neurogenesis in experimental temporal lobe epilepsy. Ann Neurol 59:81-91.

Paxinos G, Franklin KB (2001) The mouse brain in stereotaxic coordinates. London: Academic.

Pekcec A, Mühlenhoff M, Gerardy-Schahn R, Potschka H (2007) Impact of the PSA-NCAM system on pathophysiology in a chronic rodent model of temporal lobe epilepsy. Neurobiol Dis 27:54-66.

Pekcec A, Fuest C, Mühlenhoff M, Gerardy-Schahn R, Potschka H (2008) Targeting epileptogenesis-associated induction of neurogenesis by enzymatic depolysialylation of NCAM counteracts spatial learning dysfunction but fails to impact epilepsy development. J Neurochem 105:389-400.

Pekcec A, Lüpke M, Baumann R, Seifert H, Potschka H (2010) Modulation of neurogenesis by targeted hippocampal irradiation fails to affect kindling progression. Hippocampus. Advance online publication. Retrieved September 28, 2010. doi:10.1002/hipo.20802.

Pierce JP, Melton J, Punsoni M, McCloskey DP, Scharfman HE (2005) Mossy fibers are the primary source of afferent input to ectopic granule cells that are born after pilocarpine-induced seizures. Exp Neurol 196:316-331.

Radley JJ, Jacobs BL (2003) Pilocarpine-induced status epilepticus increases cell proliferation in the dentate gyrus of adult rats via a 5-HT1A receptordependent mechanism. Brain Res 966:1-12.

Rahimi O, Claiborne BJ (2007) Morphological development and maturation of granule neuron dendrites in the rat dentate gyrus. Prog Brain Res 163:167-181.

Ribak CE, Tran PH, Spigelman I, Okazaki MM, Nadler JV (2000) Status epilepticus-induced hilar basal dendrites on rodent granule cells contribute to recurrent excitatory circuitry. J Comp Neurol 428:240-253.

Scharfman HE, McCloskey DP (2009) Postnatal neurogenesis as a therapeutic target in temporal lobe epilepsy. Epilepsy Res 85:150-161.

Scharfman HE, Goodman JH, Sollas AL (2000) Granule-like neurons at the hilar/CA3 border after status epilepticus and their synchrony with area CA3 pyramidal cells: functional implications of seizure-induced neurogenesis. J Neurosci 20:6144-6158.

Scharfman HE, Sollas AE, Berger RE, Goodman JH, Pierce JP (2003) Perforant path activation of ectopic granule cells that are born after pilocarpine-induced seizures. Neuroscience 121:1017-1029.

Scharfman H, Goodman J, McCloskey D (2007) Ectopic granule cells of the rat dentate gyrus. Dev Neurosci 29:14-27.

Scheibel ME, Scheibel AB (1973) Hippocampal pathology in temporal lobe epilepsy: a Golgi survey. In: Epilepsy: its phenomena in man (Brazier $\mathrm{MAB}, \mathrm{Ed}$.). London: Academic.

Schlessinger AR, Cowan WM, Gottlieb DI (1975) An autoradiographic study of the time of origin and the pattern of granule cell migration in the dentate gyrus of the rat. J Comp Neurol 159:149-175.

Shapiro LA, Ribak CE (2006) Newly born dentate granule neurons after pilocarpine-induced epilepsy have hilar basal dendrites with immature synapses. Epilepsy Res 69:53-66.

Shapiro LA, Figueroa-Aragon S, Ribak CE (2007) Newly generated granule cells show rapid neuroplastic changes in the adult rat dentate gyrus during the first five days following pilocarpine-induced seizures. Eur J Neurosci 26:583-592.

Shapiro LA, Ribak CE, Jessberger S (2008) Structural changes for adultborn dentate granule cells after status epilepticus. Epilepsia [Suppl 5] 49:13-18.

Sugaya Y, Maru E, Kudo K, Shibasaki T, Kato N (2010) Levetiracetam suppresses development of spontaneous EEG seizures and aberrant neurogenesis following kainate-induced status epilepticus. Brain Res 1352:187-199. 
Sutula TP, Dudek FE (2007) Unmasking recurrent excitation generated by mossy fiber sprouting in the epileptic dentate gyrus: an emergent property of a complex system. Prog Brain Res 163:541-563.

Sutula T, He XX, Cavazos J, Scott G (1988) Synaptic reorganization in the hippocampus induced by abnormal functional activity. Science 239:1147-1150.

Thind KK, Ribak CE, Buckmaster PS (2008) Synaptic input to dentate granule cell basal dendrites in a rat model of temporal lobe epilepsy. J Comp Neurol 509:190-202.

Toni N, Teng EM, Bushong EA, Aimone JB, Zhao C, Consiglio A, van Praag H, Martone ME, Ellisman MH, Gage FH (2007) Synapse formation on neurons born in the adult hippocampus. Nat Neurosci 10:727-734.

Toni N, Laplagne DA, Zhao C, Lombardi G, Ribak CE, Gage FH, Schinder AF (2008) Neurons born in the adult dentate gyrus form functional synapses with target cells. Nat Neurosci 11:901-907.

Trommald M, Hulleberg G (1997) Dimensions and density of dendritic spines from rat dentate granule cells based on reconstructions from serial electron micrographs. J Comp Neurol 377:15-28. van Groen T, Miettinen P, Kadish I (2003) The entorhinal cortex of the mouse: organization of the projection to the hippocampal formation. Hippocampus 13:133-149.

van Praag H, Schinder AF, Christie BR, Toni N, Palmer TD, Gage FH (2002) Functional neurogenesis in the adult hippocampus. Nature 415: $1030-1034$.

von Campe G, Spencer DD, de Lanerolle NC (1997) Morphology of dentate granule cells in the human epileptogenic hippocampus. Hippocampus 7:472-488.

Walter C, Murphy BL, Pun RY, Spieles-Engemann AL, Danzer SC (2007) Pilocarpine-induced seizures cause selective time-dependent changes to adult-generated hippocampal dentate granule cells. J Neurosci 27:75417552.

West MJ, Andersen AH (1980) An allometric study of the area dentata in the rat and mouse. Brain Res 2:317-348.

Zhao C, Teng EM, Summers RG Jr, Ming GL, Gage FH (2006) Distinct morphological stages of dentate granule neuron maturation in the adult mouse hippocampus. J Neurosci 26:3-11. 